\title{
Effect of Heat Sterilization on the Load/Deflection of Heat-activated Orthodontic Wires
}

\author{
Dr Shiva Alavi,' Dr Seyyed Mohammad Mousavi,,2 Dr Farinaz Shirban³ \\ ${ }^{1}$ Assoc Professor, ${ }^{3}$ Asst Professor, Dental Materials Research Center, Dept of Orthodontics, School of Dentistry, \\ Isfahan University of Medical Sciences, Isfahan, Iran \\ ${ }^{2}$ Asst Professor, Dept of Orthodontics, Faculty of Dentistry, Ahvaz Jundishapour University of Medical Sciences, Ahvaz, Iran
}

\section{ABSTRACT}

Introduction: Some of the orthodontic wires are heat-activated (H-A) wires; sometimes delivered in non-sterile packages and some of whose properties can be influenced by heat treatment.

Objective: To assess the heat sterilization effects on the load/deflection (L/D) properties of H-A orthodontic wires before application.

Materials \& method: Three groups of $\mathrm{H}-\mathrm{A}$ wires $(3 \mathrm{~cm}$ length and 0.016 inches diameter) were selected; Group A: Nitinol H-A, Group B: H-A memory wire, Group C: Sentalloy H-A. Forty five samples of each type were prepared and randomly divided into three equal groups of 15 wires. Group 1 was selected as control, Group 2 was sterilized by dry heat (2 hours, $160^{\circ} \mathrm{C}$ ) and Group 3 was sterilized using steam heat ( $15 \mathrm{PSI}, 24 \mathrm{~min}, 121^{\circ} \mathrm{C}$ ). A universal testing machine was used to determine the load/deflection curve of the samples while immersed in $37^{\circ} \mathrm{C}$ water bath using 3 -bracket bending method. The force levels in loading plateau (LP) and unloading plateau (UP) were determined. One-way ANOVA and Duncan post-hoc were used for data analysis.

Result: In group A, LP and UP showed no statistical significant change. In Group B, steam heat decreased LP and UP but dry heat increased UP significantly. In Group C, steam and dry heat decreased UP and LP significantly.

Conclusion: It seems that heat sterilization could alter the L/D properties of some H-A wires depending on the type of wires and sterilization method.

Key-words: Orthodontic wires, physical properties, sterilization

\section{INTRODUCTION}

Infections are a serious hazard in orthodontic practice, because they can be transmitted directly by blood or saliva and indirectly by contaminated equipments. The sterilization process in orthodontic office is more important because of the higher number of patients than other dental practices. ${ }^{2}$ Instrument sterilization and occupational hazards in orthodontic office are discussed in dental literature..$^{3-4}$ According to the Center for Disease Control (CDC) recommendations; all instruments that are in direct contact with oral tissues should be sterilized. ${ }^{5}$ One of the most common method for sterilization in dental offices is heat sterilization. ${ }^{6}$ Orthodontic wires are frequently delivered in packages that are not sterilized and manufacturer instructions usually advise sterilization of the wires before use. ${ }^{1,7}$ Heat-activated (H-A) arch wires are orthodontic equipment in which the crystalline transformation is induced by oral temperatures. ${ }^{8}$ Advantages of $\mathrm{H}$-A wires include easier wire insertion, lighter and more stable force, less ageing and more resistance to corrosion, that result in optimum tooth movements with lower complications; ${ }^{8-9}$ so they have become popular in recent years.

Heat has a significant effect on the nature and number of material phases. Because most of the materials used in orthodontics have at least two phases, the derived instruments can be affected by heat processes. The properties of Nitinol wires are credited to their transformation between austenite (higher temperature) and martensite (lower temperature) phase. Niti wires are plastically deformed in their martensite phase, when heated above transformation temperature they will return to an austenite phase and initial form. Some studies found wires were influenced by temperature changes. Burston et al demonstrated that heat more than $60^{\circ} \mathrm{C}$ on superelastic wires increase the susceptibility to permanent deformation and decrease their spring back. ${ }^{10}$ Heat processes can change the mechanical properties of Ni-Ti alloy depending on the heat treatment temperature and time." Aghamiri et al showed heat treatments can change the phase, chemical composition and finally mechanical properties of $\mathrm{H}-\mathrm{A}$ wires. ${ }^{12}$ 
Berzins et al indicated that repeated temperature fluctuations can cause qualitative and quantitative changes in some Ni-Ti wires. ${ }^{13}$ Most of the researches conducted on heat treatment and rectangular wires with contradictory results, $12,14,15$ so we designed current study to determine the effect of heat sterilization on load/deflection (L/D) properties of round H-A wires. Due to changes the characteristics of wires based on the aforementioned discussion, it is important to determine the effect of heat sterilization process as having adverse effects on $\mathrm{H}-\mathrm{A}$ wires or not.

\section{MATERIALS AND METHOD}

\section{Testing Arch Wires:}

Three groups of 0.016 inch H-A wires, Group A: Nitinol H-A (3M, Unitek, Monrovia, California, USA) with 27 transition temperature range (TTR), Group B: Titanium H-A (American Orthodontic, Sheboygan, Wisconsin, USA) with 28 TTR and Group C: Sentalloy H-A (GAC International, Inc, Central Islip, New York, USA) with 28 TTR were selected. Specimens were prepared with similar lengths $(3 \mathrm{~cm})$ from straight posterior buccal segment which, based on practical experience, show less stress during manufacturing and are capable of tolerating more uniform stresses during 3-bracket bending test. These wires were sectioned by turbine and diamond bur with air and water coolant to minimize the mechanical and thermal stress and possible microstructural alteration. ${ }^{8}$ Then, each type of wire was randomly divided into three groups of 15 specimens. From each type of wire, one group was selected as control. The second group was sterilized by dry heat and the third group was sterilized by steam heat.

\section{Sterilization Methods:}

Dry heat sterilization was done with $160^{\circ} \mathrm{C}$ temperature for 2 hours in oven (Dentronix DDS 5000; Ivyland, Pennsylvania, USA). Steam heat sterilization was performed with $121^{\circ} \mathrm{C}$ temperature and $15 \mathrm{PSI}$ for 15 minutes in autoclave (Euroklav 23 VS; Melag, Berlin, Germany). All sterilized specimens were gradually cooled in the oven and autoclave.

\section{Test Method:}

Then the samples underwent a three-point load-deflection test as described by Miura et $a^{16}$ a specially designed setup with three cylinders and one sheet of copper were used to set up a 3-bracket bending test device. One standard maxillary canine bracket (0.018 inch slot) (American Orthodontics, Master Series, Wisconsin, USA) was mounted on each cylinder with zero angulation and zero torque (Figure.1).
Considering that $\mathrm{H}-\mathrm{A}$ wires manifest optimum mechanical properties in the mouth temperature, the tests were carried out in a $37^{\circ} \mathrm{C}$ water bath. Thermocouple and thermostat were used to retain the bath water temperature at $37^{\circ} \mathrm{C}$ with $0.1^{\circ} \mathrm{C}$ accuracy.

The 3-bracket bending device was fixed at the bottom of the water bath and all tests were done in the same depth of water using universal testing machine (Testometric 500-25kN; Testometric Co. Ltd., Lancashire, England) and $5 \mathrm{~kg}$ loading cell with $0.5 \mathrm{~mm} / \mathrm{min}$ speed and $2.4 \mathrm{~mm}$ range. Elastomeric ligatures (Ortho Organizers, Carlsbad, California, USA) maintained the wires in the bracket slots. Win test analysis materials testing software was used to measure the force levels at each $0.2 \mathrm{~mm}$ bending; for every specimen, 12 force levels during loading and 12 force levels during unloading were obtained. Each wire was tested three times and the software determined the average force level and load/deflection curves of each wire. After checking all curves and determining the totally flat segments in loading and unloading curves, the average force level between 1-2 mm deflection during loading was selected as the loading plateau (LP) and the average force level between 1-2 mm deflection during unloading was selected as the unloading plateau (UP). Data were analyzed by SPSS 16.0 software using one-way ANOVA and Duncan post-hoc test. Statistical significance was set at $p=0.05$.

\section{RESULT}

In group A, dry and steam heat sterilization did not have any significant effect on the LP and UP of the wires as compared to the control group (Table 1).

In group B, steam heat sterilization significantly decreased the LP as compared to dry heat sterilization and control group (P:0.043). Dry heat sterilization significantly increased the UP in comparison to the steam heat sterilization and control group (P:0.008) (Table 2).

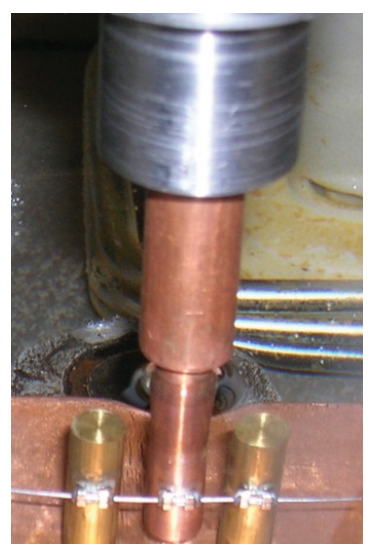

Figure 1: Bending test device 
Table 1: Nitinol heat activated wire (Group A)

\begin{tabular}{|l|c|c|}
\hline \multicolumn{1}{|c|}{ Unloading plateau (UP) } & Loading plateau (LP) & Parameters \\
\hline Dry-Heat Sterilization & $217.2 \pm 10 \mathrm{~g}$ & $417.3 \pm 53 \mathrm{~g}$ \\
\hline Dry- Heat Sterilization & $228 \pm 11.4 \mathrm{~g}$ & $399.2 \pm 29.9 \mathrm{~g}$ \\
\hline Steam - Heat Sterilization & $217.7 \pm 18.7 \mathrm{~g}$ & $404.3 \pm 22 \mathrm{~g}$ \\
\hline
\end{tabular}

Table 2: Titanium heat activated wire (Group B)

\begin{tabular}{|l|c|c|}
\hline \multicolumn{1}{|c|}{ Unloading plateau (UP) } & Loading plateau (LP) & Parameters \\
\hline Dry-Heat Sterilization & $143.3 \pm 7.2 \mathrm{~g}$ & $372.1 \pm 30.2 \mathrm{~g}$ \\
\hline Dry-Heat Sterilization & $160.1 \pm 7.4 \mathrm{~g}^{*}$ & $382.3 \pm 27.2 \mathrm{~g}$ \\
\hline Steam - Heat Sterilization & $136 \pm 9.5 \mathrm{~g}$ & $348.7 \pm 9.3 \mathrm{~g}^{*}$ \\
\hline
\end{tabular}

Table 3: Sentalloy heat activated wire (Group C)

\begin{tabular}{|l|c|c|}
\hline \multicolumn{1}{|c|}{ Unloading plateau (UP) } & Loading plateau (LP) & Parameters \\
\hline Dry - Heat Sterilization & $173.5 \pm 9.4 \mathrm{~g}$ & $383.4 \pm 24.6 \mathrm{~g}$ \\
\hline Dry - Heat Sterilization & $138.5 \pm 7 \mathrm{~g}^{*}$ & $309.5 \pm 9.4 \mathrm{~g}^{*}$ \\
\hline Steam - Heat Sterilization & $135.1 \pm 5.9 \mathrm{~g}^{*}$ & $306.9 \pm 8 \mathrm{~g}^{*}$ \\
\hline
\end{tabular}

*significant $(p<0.05)$

\section{DISCUSSION}

In the current study, the effect of both dry and steam sterilization on the force level of three groups of $\mathrm{H}$-A wires was assessed. Optimum orthodontic force is the lightest force that can stimulate maximal biologic response in periodontal ligaments. When a wire is deflected for insertion in the bracket of crowded teeth, "loading" occurs whereas, when the wire tends to regain its original shape, "unloading" occurs; therefore, the "unloading" force of the wire provides clinical biologic response. ${ }^{17}$ Small variation in the manufacturing process such as in nickel and oxygen content, heat treatment and work hardening history has significant impacts on arch wires. ${ }^{14,18}$ Sterilizer temperatures might influence the mechanical properties of wires. ${ }^{19}$ That's why recent studies are focused on the effect of time and heat treatment on the mechanical properties of Ni-Ti wires. The effect of heat treatment on Ni-Ti wires is complex and depends on the degree of working. If the degree of working is increased Ni-Ti alloy tends to harden and lose its superelastic properties, similar to other metals. ${ }^{11}$ In some studies, these changes have contributed to the change in the austenite phase of Ni-Ti alloy. ${ }^{20-22}$ Laino et al showed that superelastic behaviour of wire is affected by the ambient temperature changes. ${ }^{23}$

In this study, the effect of both dry and steam sterilization on the force level of three groups of $\mathrm{H}-\mathrm{A}$ wires was assessed. Based on the results obtained, the aforementioned processes do not have any influence on the force level of Nitinol H-A wires (3M, Unitek) during the "loading" and "unloading" phases; hence, clinicians can sterilize this wire before application without any undue concern. After steam heat sterilization, titanium $\mathrm{H}-\mathrm{A}(\mathrm{AO})$ wires need lower force for insertion due to the decreased LP and they also exert lower force onto the teeth because of the decreased UP. But these wires exert more force on the teeth after sterilization via dry heat because of the increased UP. Comparison of the results of previous studies demonstrates that the plateau length and force between wires tested in different temperatures are variable. ${ }^{24,25}$ Different reactions of the wires to various heat sterilization processes can contribute to more time and temperature and no humidity in dry heat sterilization. In sentalloy H-A (GAC) wires, after sterilization using both wet and dry heat, the force level in the LP and UP decreases, which explains easier wire insertion and less force delivery to the teeth.

Thus, it can be inferred that the reaction of $\mathrm{H}$-A wires to heat sterilization depends on the composition of wire alloy, heat treatment during manufacturing and the type of sterilization process. 


\section{CONCLUSION}

Heat-activated wires tested in current study showed significant change related to sterilization as well as mechanical characteristics and force except Nitinol $\mathrm{H}-\mathrm{A}$ (3M, Unitek ). However in vivo studies are required to substantiate the result of this study.

\section{ACKNOWLEDGEMENT}

This report is based on part of a Grant (\#388059) submitted to the Vice Chancellery for Research, Isfahan University of Medical Sciences, Isfahan, Iran.

\section{REFERENCES}

1. Mastaj L, Tartakow D, Borislow A, Fogel M. Infection control in the dental practice with emphasis on the orthodontic practice. Compendium $1994 ; 15: 74,6,8$.

2. Mulick JF. Upgrading sterilization in the orthodontic practice. Am J Orthod. 1986;89:346-51.

3. Kangane SK. Instrument sterilization in the orthodontic clinic: A review. Int Journal of Clinical Dental Science. 201 1; 1:53-8.

4. Ayatollahi J, Ayatollahi F, Ardekani AM, Bahrololoomi R, Ayatollahi J, Ayatollahi A, et al. Occupational hazards to dental staff. Dent Res J (Isfahan). 2012; 9:2-7

5. Cash RG. Trends in sterilization and disinfection procedures in orthodontic offices. Am J Orthod Dentofacial Orthop 1990; $98: 292-9$.

6. Vendrell RJ, Hayden CL, Taloumis LJ. Effect of steam versus dry-heat sterilization on the wear of orthodontic ligature-cutting pliers. Am J Orthod Dentofacial Orthop 2002; 121:467-71.

7. Pernier C, Grosgogeat B, Ponsonnet L, Benay G, Lissac M. Influence of autoclave sterilization on the surface parameters and mechanical properties of six orthodontic wires. The Eur J Orthod 2005; 27:72-81.

8. Biermann MC, Berzins DW, Bradley TG. Thermal analysis of as-received and clinically retrieved copper-nickel-titanium orthodontic archwires. Angle Orthod 2007; 77:499-503.

9. Gil F, Planell J. Effect of copper addition on the superelastic behavior of Ni-Ti shape memory alloys for orthodontic applications. J Biomed Mater Res 1999; 48:682-8.

10. Burstone CJ, Qin B, Morton JY. Chinese NiTi wire-A new orthodontic alloy. Am J Orthod 1985; 87:445-52.

11. Harris EF, Newman SM, Nicholson JA. Nitinol arch wire in a simulated oral environment. Changes in mechanical properties. Am J Orthod Dentofacial Orthop 1988; 93:508-13.

12. Seyyed Aghamiri S, Ahmadabadi MN, Raygan S. Combined effects of different heat treatments and Cu element on transformation behavior of NiTi orthodontic wires. J Mech Behav Biomed Mater 2011; 4:298-302.

13. Berzins DW, Roberts HW. Phase transformation changes in thermocycled nickel-titanium orthodontic wires. Dent Mater 2010; $26: 666-74$.

14. Meling TR, $\varnothing$ degaard J. The effect of temperature on the elastic responses to longitudinal torsion of rectangular nickel titanium archwires. Angle Orthod 1998; 68:357-68.

15. Sakima MT, Dalstra M, Melsen B. How does temperature influence the properties of rectangular nickel-titanium wires? Eur J Orthod 2006 28:282-91.

16. Miura F, Mogi M, Ohura Y, Hamanaka H. The super-elastic property of the Japanese NiTi alloy wire for use in orthodontics. Am J Orthod Dentofacial Orthop 1986; 90:1-10.

17. Kapila S, Haugen JW, Watanabe LG. Load-deflection characteristics of nickel-titanium alloy wires after clinical recycling and dry heat sterilization. Am J Orthod Dentofacial Orthop 1992; 102:120-6.

18. Mo W, Choe H, Ko Y. Effect of drawing method on the mechanical properties and corrosion resistance of stainless steel wire for use in orthodontics. J Dent Res 2003; 82:341-2.

19. Alavi S, Sinaee N. Effect of dry heat and steam sterilization on load-deflection characteristics of $\beta$-titanium wires: An in vitro study. Den Res J (Isfahan) 2012; 9:541-8.

20. Fariabi S, AbuJudom DN, Thoma PE. Effect of heat treatment after cold working on the phase transformation of near equiatomic Ni-Ti shape memory alloys.Sydney: Material Science Forum, Proc ICOMAT 1989; 565:56-8.

21. Todoroki T, Tamura H. Effect of heat treatment after cold working on the phase transformation in TiNi alloy. Trans Jpn Inst Met 1987; 28:8394

22. Miura F, Mogi M, Ohura Y. Japanese NiTi alloy wire: use of the direct electric resistance heat treatment method. Eur J Orthod. 1988; 10:18791.

23. Laino G, De Santis R, Gloria A, Russo T, Quintanilla DS, Laino A, Martina R, et al . Calorimetric and thermomechanical properties of titanium-based orthodontic wires: DSC-DMA relationship to predict the elastic modulus. J Biomater Appl 2012; 26:829-44.

24. Lombardo L, Marafioti M, Stefanoni F, Mollica F, Siciliani G. Load deflection characteristics and force level of nickel titanium initial archwires. Angle Orthod 2011;82:507-21.

25. Lombardo L, Toni G, Stefanoni F, Mollica F, Guarneri MP, Siciliani G. The effect of temperature on the mechanical behavior of nickeltitanium orthodontic initial archwires. Angle Orthod 2012; 83:298-305. 